\title{
ANALISIS MANAJEMEN KINERJA GURU (Studi Kasus Madrasah Aliyah Al Ayyubi di Sidoarjo)
}

\author{
Rizki Amalia Putri* \\ Fakultas Ekonomi Universitas Nahdlatul Ulama Sidoarjo \\ e-mail: Rizkiamalia.fe.unusida@gmail.com
}

\begin{abstract}
Analysis of Performance Management Teacher Madrasah Aliyah Al Ayyubi In Sidoarjo Madrasah Aliyah Al Ayyubi is a private institution located in Sidoarjo East Java. Since 2011 until now, the problem arises that there are indications of not achieving satisfactory performance. This research uses a qualitative approach, which is trying to get as complete information as possible about the performance management of teachers at Madrasah Aliyah Al Ayyubi. Qualitative techniques are used as an approach in this study, because this technique is to understand rational reality as subjective reality especially madrasah citizens to formulate more concrete about teacher performance management.

The result is that the existing performance management system in Madrasah Aliyah Al Ayyubi is said to be running almost 60\%, in the planning phase Madrasah Aliyah Al Ayyubi has a work program that has been aligned as needed with vision, mission, target and madrasah strategy. However, in its implementation, out of 2 training models defined in the work program, monthly training that includes computer courses and case studies, many of the less participating senior teachers are different from junior teachers who welcome the effort.

Another disadvantage of the performance management system in Madrasah Aliyah Al Ayyubi lies in performance evaluation, there is no formal and formal assessment format by Madrasah Aliyah Al Ayyubi and still uses the method of personal discussions and hearings, although previously held daily observations, Weekly and monthly performance of teachers in terms of discipline and teacher competence.
\end{abstract}

Keywords: performance management, teacher, performance

\section{PENDAHULUAN}

Pembangunan merupakan proses berkesinambungan yang mencakup seluruh aspek kehidupan masyarakat, termasuk aspek sosial, ekonomi, politik dan kultural dengan tujuan utama meningkatkan kesejahteraan warga bangsa secara keseluruhan. Dalam proses pembangunan tersebut peranan pendidikan amatlah strategis. Berdasarkan peran strategis pendidikan dalam pembangunan itu, tidak mengherankan apabila kemudian pemerintah dan masyarakat memberi perhatian yang cukup besar terhadap masalah pendidikan. Perhatian besar pemerintah dan masyarakat itu salah satunya tampak dalam upaya mewujudkan masyarakat yang dapat menge- nyam pendidikan secara merata, artinya baik pemerintah maupun masyarakat mengupayakan adanya sarana pendidikan berupa sekolah atau madrasah dari jenjang pendidikan dasar hingga pendidikan menengah, sehingga dengan adanya sarana tersebut masyarakat dapat menikmati proses pendidikan dalam suatu lembaga formal.

Upaya mencapai pendidikan sekolah/madrasah yang bermutu tentu harus melibatkan semua komponen yang ada di dalamnya, seperti pemimpin atau kepala sekolah/madrasah, guru, pegawai dan stakeholder (Fuad dkk., 2006). Dalam upaya mencerdaskan kehidupan bangsa, perkembangan dan perubahan secara terus menerus menuntut perlunya perbaikan sistem pendidikan nasional 
termasuk manajemen berbasis sekolah (MBS) untuk mewujudkan masyarakat yang mampu bersaing dan menjawab tantangan perubahanperubahan zaman. Manajemen sekolah dipandang sebagai suatu pendekatan pengelolaan sekolah dalam rangka desentralisasi pendidikan yang memberikan wewenang yang luas kepada sekolah untuk mengambil keputusan mengenai pengelolaan sumber daya pendidikan sekolah.

Madrasah dan sekolah, keduanya mempunyai karakteristik atau ciri khas yang berbeda. Madrasah memiliki kurikulum, metode dan cara mengajar sendiri yang berbeda dengan sekolah, meskipun mengajarkan ilmu pengetahuan umum sebagaimana yang diajarkan di sekolah, madrasah memiliki karakter tersendiri, yaitu sangat menonjolkan nilai-nilai budaya religious. Sementara itu sekolah merupakan lembaga pendidikan umum dengan pelajaran universal (Karel Steenbrink, 1986).

Dalam upaya mencerdaskan kehidupan bangsa, guru yang juga disebut sebagai pendidik dan merupakan salah satu tenaga kependidikan, menempati kedudukan yang sangat penting, dengan profesionalismenya serta hubungan yang dekat dengan peserta didik ia berperan dalam menciptakan lingkungan belajar yang kondusif. Undang-Undang No. 20 Tahun 2003 tentang Sistem Pendidikan Nasional menyatakan bahwa pendidik merupakan tenaga profesional yang bertugas merencanakan dan melaksanakan proses pembelajaran, menilai hasil belajar, melakukan bimbingan dan pelatihan, serta melakukan penelitian dan pengabdian kepada masyarakat $(\mathrm{Mu}-$ farrihah, 2008: hal 1).

Kemampuan guru dalam membuat desain instruksional akan sangat berpengaruh terhadap kemampuan siswa khususnya hasil belajar yang akan dicapai. Jadi tugas profesional guru yang sangat penting dan erat sekali dengan kegiatan pembelajaran adalah pembuatan desain instruksional atau rancangan pembelajaran yang harus dikuasai oleh setiap guru. Kemampuan guru dalam mengajar dituntut selalu meningkat selaras dengan kemajuan ilmu pengetahuan dan teknologi agar kegiatan interaksi belajar-mengajar semakin hidup (Mufarrihah, 2008).

Kebutuhan akan guru profesional yang makin mendesak sejalan dengan tuntutan akan kapasitas mereka untuk menjadi manajer kelas yang baik. Hal ini karena di samping melakukan tugas kependidikan dan pembelajaran, guru juga melaksanakan tugas manajemen atau administrasi kelas. Kemampuan guru dalam mengelola kelas ini menjadi salah satu tolak ukur kemampuan profesional mereka karena kebutuhan dan tuntutan akan guru yang profesional menjadi sangat esensial, terlebih lagi lembaga pendidikan semakin dituntut untuk menghasilkan lulusan yang bermutu (Maidatul Jannah, 2006).

Tugas guru erat kaitannya dengan peningkatan sumber daya manusia melalui sektor pendidikan (Tilaar, H. AR: 1999). Menurut Pfeffer (1994) sumber daya manusia dalam sebuah organisasi menjadi sarana penting dalam meraih keunggulan kompetitif, dan pengelolaan sumber daya manusia dalam organisasi yang mampu meningkatkan kinerja organisasi adalah manajemen kinerja. Manajemen kinerja bisa berfokus pada kinerja dari suatu organisasi, departemen, karyawan, atau bahkan proses untuk menghasilkan produk atau layanan, dan juga di area yang lain baik di tingkat organisasi ataupun individu, salah satu fungsi kunci dari manajemen adalah mengukur dan mengelola kinerja (Brudan, 2010).

Pilihan peneliti terhadap lembaga pendidikan ini didasarkan pada suatu fenomena, Madrasah Aliyah Al Ayyubi merupakan sebuah lembaga swasta yang berlokasi di Sidoarjo Jawa 
Timur. Madrasah Aliyah Al Ayyubi didirikan pada tahun 2012 dengan jumlah siswa yang dimiliki saat itu 51 siswa. Pada tahun berikutnya mulai mengalami kenaikan menjadi 80 siswa, sedang di tahun ketiga berjumlah 178 siswa, tahun selanjutnya berjumlah 202 siswa dan hingga tahun 2017 jumlahnya mencapai 246 siswa.

Sejak tahun 2012 hingga saat ini, muncul permasalahan yakni ada indikasi belum tercapainya kinerja yang memuaskan sehingga belum menampakkan hasil yang diinginkan.

Fenomena lain muncul dari pihak eksternal yang berkaitan dengan citra madrasah yakni menurunnya kepercayaan masyarakat atau orang tua untuk menyekolahkan putra-putrinya di Madrasah Aliyah Al Ayyubi

\section{KERANGKA TEORETIS}

Herman Aguinis (2009, hal. 2) menyebutkan bahwa "Performance management is a continuous process of identifying, measuring, and developing the performance of individuals and teams and aligning performance with the strategic goal of the organization".

Senada dengan Robert Bacal (2001) yang mengemukakan bahwa manajemen kinerja, sebagai sebuah proses komunikasi yang berkesinambungan dan dilakukan dalam kemitraan antara seorang karyawan dan penyelia langsungnya. Proses ini meliputi kegiatan membangun harapan yang jelas serta pemahaman mengenai pekerjaan yang akan dilakukan. Ini merupakan sebuah sistem, artinya ia memiliki sejumlah bagian yang semuanya harus diikutsertakan kalau sistem manajemen kinerja ini hendak memberikan nilai tambah bagi organisasi, manajer dan karyawan.

Berdasarkan ungkapan di atas, manajemen kinerja di madrasah/sekolah terutama berkaitan erat dengan tugas kepala madrasah/sekolah untuk selalu melakukan komunikasi yang berkesinambungan, melalui jalinan kemitraan dengan seluruh guru dan pegawainya (Akhmad Sudrajat, 2008). Selanjutnya, Robert Bacal (2001) mengemukakan pula bahwa dalam manajemen kinerja di antaranya meliputi perencanaan kinerja, komunikasi kinerja yang berkesinambungan dan evaluasi kinerja.

Perencanaan kinerja merupakan suatu proses di mana guru dan kepala sekolah/madrasah bekerja sama merencanakan apa yang harus dikerjakan guru pada tahun mendatang, menentukan bagaimana kinerja harus diukur, mengenali dan merencanakan cara mengatasi kendala, serta mencapai pemahaman bersama tentang pekerjaan itu. Komunikasi yang berkesinambungan merupakan proses di mana kepala sekolah/madrasah dan guru bekerja sama untuk saling berbagi informasi mengenai perkembangan kerja, hambatan dan permasalahan yang mungkin timbul, solusi yang dapat digunakan untuk mengatasi berbagai masalah, dan bagaimana kepala sekolah dapat membantu guru. Arti pentingnya terletak pada kemampuannya mengidentifikasi dan menanggulangi kesulitan atau persoalan sebelum itu menjadi besar (Akhmad Sudrajat: 2008).

Akhmad Sudrajat (2008) juga menyebutkan bahwa evaluasi kinerja yang merupakan salah satu bagian dari manajemen kinerja, sebagaimana dijelaskan oleh Robert Bacal (2001) yakni merupakan sebuah proses di mana kinerja perseorangan dinilai dan dievaluasi. Hal ini dipakai untuk menjawab pertanyaan, "Seberapa baikkah kinerja seorang guru pada suatu periode tertentu?” Metode apapun yang dipergunakan untuk menilai kinerja, penting sekali bagi kita untuk menghindari dua perangkap. Pertama, tidak mengasumsikan masalah kinerja terjadi secara terpisah satu sama lain, atau "selalu salahnya guru”. 
Kedua, tiada satu pun taksiran yang dapat memberikan gambaran keseluruhan tentang apa yang terjadi dan mengapa. Penilaian kinerja hanyalah sebuah titik awal bagi diskusi serta diagnosis lebih lanjut.

\section{METODE}

Penelitian ini menggunakan pendekatan kualitatif. Pendekatan kualitatif memungkinkan peneliti untuk memberikan interpretasi yang rumit pada suatu fenomena dalam menemukan makna yang sesungguhnya. Penelitian kualitatif meliputi mengumpulkan, menganalisis, dan menginterpretasikan data dengan mengobservasi pernyataan dari seseorang (Burn\& Bush, 2012: hal. 114).

Penelitian ini menggunakan pendekatan kualitatif, yaitu berusaha mendapatkan informasi yang selengkap mungkin mengenai manajemen kinerja guru pada Madrasah Aliyah Al Ayyubi. Teknik kualitatif dipakai sebagai pendekatan dalam penelitian ini, karena teknik ini untuk memahami realitas rasional sebagai realitas subjektif khususnya warga madrasah guna merumuskan lebih konkret tentang manajemen kinerja guru. Hasilnya akan digunakan sebagai bahan pertimbangan dalam menentukan kebijakan-kebijakan yang mendukung kelangsungan madrasah.

Desain penelitian merupakan suatu rancangan berupa rangkaian pertanyaan awal yang harus dijawab dan kemudian serangkaian konklusi atau dengan kata lainnya jawaban dari pertanyaan-pertanyaan yang diajukan sebelumnya. Untuk mencapainya dibutuhkan berbagai langkah pokok termasuk pengumpulan dan analisis data yang relevan. Komponen-komponen desain penelitian adalah: pertanyaan penelitian, proposisi, unit analisis, pengaitan logis antara data dengan proposisi, dan kriteria untuk mengintepretasikan temuan (Yin, 2009, hal 29).

\section{ANALISIS DAN PEMBAHASAN}

Penelitian ini menggunakan analisis pattern-matching yaitu dengan membandingkan logika berpikir secara empiris yang didasarkan pada suatu pola tertentu dan yang didasarkan pada satu atau beberapa prediksi tertentu. Jika terdapat kesamaan antara yang diprediksi dengan kenyataan yang terjadi, maka hal ini akan memperkuat internal validity dari penelitian ini. Dalam penelitian studi kasus yang merupakan penelitian eksplanatori, pattern-matching berhubungan dengan proposisi sebagai berikut.

1. Analisis kondisi Madrasah Aliyah Al Ayyubi terkait penerapan visi, misi, sasaran dan strategi madrasah.

2. Analisis kinerja guru sesuai standar kinerja guru Madrasah Aliyah Al Ayyubi.

3. Analisis sistem manajemen kinerja guru Madrasah Aliyah Al Ayyubi.

\section{a. Pembahasan Proposisi 1: Analisis Kondisi Madrasah Aliyah Al Ayyubi}

Dari hasil wawancara dengan key informants yang telah dipilih dengan alasan pemilihan yang telah dijelaskan di diketahui bahwa kinerja madrasah yang ideal adalah madrasah yang mampu mencapai visi, misi dan sasaran serta strategi yang telah ditetapkan dan disepakati bersama. Sedangkan kinerja madrasah dipengaruhi oleh kinerja guru yang harus sesuai dengan standar yang telah ditetapkan sebelumnya.

Madrasah Aliyah Al Ayyubi salah satu lembaga pendidikan yang diberikan tugas untuk mewujudkan tujuan pendidikan nasional harus menjalankan perannya dengan baik. Agar pengelolaan madrasah tersebut dapat berjalan dengan baik, dibutuhkan rencana strategis sebagai suatu upaya/cara untuk mengendalikan organisasi (madrasah) secara efektif dan efisien, sampai kepada 
implementasi sehingga tujuan dan sasarannya tercapai. Perencanaan strategis merupakan landasan bagi Madrasah Aliyah Al Ayyubi dalam menjalankan proses pendidikan. Komponen dalam perencanaan strategis paling tidak terdiri dari visi, misi, sasaran dan strategi (cara mencapai tujuan dan sasaran).

\section{Pembahasan Data Hasil Penelitian Terkait Proposisi 1}

Dari data penelitian hasil observasi dan wawancara dengan pimpinan madrasah (kepala madrasah, wakamad kurikulum, wakamad sarana dan prasarana, wakamad kesiswaan, wakamad humas), didapatkan bahwa pada Madrasah Aliyah Al Ayyubi terdapat upaya sosialisasi visi, misi, sasaran dan strategi kepada seluruh anggota organisasi. Hal ini dibuktikan dari hasil wawancara kepada key informant, pimpinan madrasah tampak antusias dan lancar ketika menjelaskan tentang visi dan misi madrasah. Akan tetapi, pada penerapannya melalui sasaran dan strategi yang telah disepakati secara bersama oleh seluruh anggota organisasi, masih belum bisa dikatakan sempurna karena terdapat banyak kendala. Salah satunya dari faktor sarana dan prasarana yang belum memadai seperti pengadaan komputer untuk laboratorium bahasa serta pengadaan buku-buku perpustakaan. Kemudian ada peranan guru yang kurang fokus dalam menjalankan pekerjaan di Madrasah Aliyah Al Ayyubi karena terbentur jadwal lain di Mts Madrasah Aliyah Al Ayyubi. Diketahui dari pimpinan madrasah, terdapat 8 orang guru yang juga merangkap jabatan di Madrasah Tsanawiyah Abil Hasan Asy Syadzili, sehingga membuat konsentrasi mereka terpecah. Hal ini dibuktikan ketika observasi, terdapat kelas kosong dengan alasan guru tersebut sedang rapat di kantor Mts Madrasah Aliyah Al Ayyubi.
Kendala lain yakni kekurangan tenaga pengajar yang memang khusus mendalami mata pelajaran tersebut. Pada bidang mata pelajaran umum, yakni matematika, fisika, bahasa inggris serta teknologi informatika dan kesenian (TIK), semisal guru pada mata pelajaran matematika dan fisika adalah sarjana lulusan kedokteran hewan, guru teknologi informatika dan kesenian adalah sarjana lulusan ilmu sosial.

Dari hasil penelitian terkait dengan proposisi yang telah diuraikan maka dapat ditarik kesimpulan bahwa kinerja Madrasah Aliyah Al Ayyubi saat ini terkait penerapan visi, misi, sasaran dan strategi madrasah belum tercapai secara maksimal. Masih terdapat banyak kendala yang belum bisa diselesaikan.

\section{b. Pembahasan Proposisi 2: Analisis Kinerja Guru - Standar Kinerja Guru Madrasah Aliyah Al Ayyubi}

Berdasarkan penelitian, didapatkan hasil bahwa kinerja guru Madrasah Aliyah Al Ayyubi belum memenuhi standar kompetensi sesuai dengan Peraturan Menteri Pendidikan Nasional Republik Indonesia Nomor 16 Tahun 2007 tentang Standar Kualifikasi Akademik dan Kompetensi Guru, yakni kompetensi pedagogik, kompetensi kepribadian, kompetensi sosial dan kompetensi professional. Hal ini terbukti dari hasil wawancara dan observasi di mana mulai dari kompetensi pendagogik yang meliputi pemahaman guru terhadap peserta didik, perancangan dan pelaksanaan pembelajaran, evaluasi hasil belajar, dan pengembangan peserta didik untuk mengaktualisasikan berbagai potensi yang dimilikinya masih belum terlaksana dengan baik. Pada perancangan dan pelaksanaan pembelajaran, di mana seharusnya guru harus memiliki rencana pembelajaran berupa silabus serta mampu mengelola kelas, memanfaatkan komputer 
dan LCD sebagai media proses pembelajaran dan membangun keaktifan siswa dalam diskusi interaktif antara guru Madrasah Madrasah Aliyah Al Ayyubi sebagian besar tidak melakukan hal tersebut, khususnya guru-guru senior dengan keterbatasan kemampuan ketika mengoperasikan komputer dan LCD.

Selain itu, dalam kompetensi kepribadian, di mana seorang guru harusnya mampu menjadi teladan yang digugu lan ditiru atau yang selalu benar dan patut di contoh justru menampakkan sikap yang kurang baik. Mengingat bahwa Madrasah Aliyah Al Ayyubi ini merupakan lembaga pendidikan yang juga bernapaskan agama Islam, maka lembaga ini sangat memperhatikan segala tindak laku agar selalu sinkron dengan nilainilai ajaran agama Islam. Hampir setiap kali observasi, selalu terdapat guru yang melanggar peraturan madrasah untuk sholat dhuhur berjama'ah di masjid Al Ayyubi milik yayasan.

Poin plusnya justru terdapat pada kompetensi sosial, guru-guru di Madrasah Aliyah Al Ayyubi ini tidak memilih teman baik dari kalangan yang pintar atau yang sebaliknya dan dari kalangan yang kaya atau yang miskin, dan semua guru mampu menyesuaikan diri dalam bermasyarakat dan saling berbagi pengalaman serta bersikap ramah, sopan santun dan terbuka. Mereka juga memiliki pengalaman yang luas sehingga guru mampu menerima atau membagi suatu pengalaman, yang bisa memberikan masukan yang baik dan guru juga mampu beradaptasi dalam suatu lingkungan sekitar maupun dalam bermasyarakat.

Kompetensi profesional yang dimiliki oleh guru-guru Madrasah Aliyah Al Ayyubi ini sekalipun belum optimal, akan tetapi sudah mempunyai akar fondasi yang bagus. Hal tersebut terbukti dari para guru yang merupakan lulusan dari perguruan tinggi baik negeri maupun swasta, berada di jurusan yang sesuai dengan mata pelajaran yang diampu. Semisal mata pelajaran ekonomi yang dipegang oleh guru lulusan sarjana ekonomi, mata pelajaran agama (bahasa Arab, Alqur'an hadist, sejarah kebudayaan Islam, aqidah akhlaq, dan fiqh) oleh sarjana lulusan agama, sedangkan sisanya yakni mata pelajaran bahasa Indonesia, sosiologi, PPKN, geografi, fisika, biologi, kesenian, dan sejarah oleh guru lulusan sarjana pendidikan. Meski untuk mata pelajaran matematika, terdapat satu orang guru yang mengajar adalah sarjana lulusan kedokteran hewan dengan alasan karena faktor hubungan kekerabatan antara guru matematika tersebut dengan ketua yayasan.

Kompetensi professional berkaitan erat dengan ketiga kompetensi, yakni kompetensi pedagogik, kompetensi kepribadian dan kompetensi sosial. Menilik dari penjabaran dari ketiga kompetensi yang telah dijelaskan di atas dapat diketahui tingkat kompetensi guru-guru di Madrasah Aliyah Al Ayyubi ini cenderung belum menunjukkan profesionalisme yang sempurna. Masih banyak kekurangan di beberapa sektor kompetensi.

\section{c. Pembahasan Proposisi 3: Sistem Manajemen Kinerja Guru - Sistem Manajemen Kinerja Guru Madrasah Aliyah Al Ayyubi}

Madrasah Aliyah Al Ayyubi merupakan madrasah swasta yang bercirikan Islam dan mengutamakan kualitas peserta didik serta mengedepankan akhlaqul karimah, dengan demikian tentunya lembaga tersebut harus memiliki tenaga pengajar yang profesional, serta memiliki kinerja dan kemampuan yang tinggi.

Dalam perspektif manajemen, agar kinerja guru dapat selalu ditingkatkan dan mencapai standar tertentu, maka dibutuhkan suatu manajemen kinerja yang mengacu pada prinsip manajemen yang meliputi tiga fase yakni perencanaan, pembinaan, dan evaluasi. Perencanaan merupa- 
kan fase pendefinisian dan pembahasan peran, tanggung jawab, dan ekspektasi yang terukur. Perencanaan tadi membawa pada fase pembinaan,- di mana guru dibimbing dan dikembangkan - mendorong atau mengarahkan upaya mereka melalui dukungan, umpan balik, dan penghargaan. Kemudian dalam fase evaluasi, kinerja guru dikaji dan dibandingkan dengan ekspektasi yang telah ditetapkan dalam rencana kinerja.

\section{Pembahasan Data Hasil Penelitian Terkait dengan Proposisi 3}

Berdasarkan penelitian yang telah dilakukan, yakni melalui observasi dan wawancara dengan key informants diketahui bahwa sistem manajemen kinerja guru di Madrasah Aliyah Al Ayyubi ini sesuai dengan elemen manajemen kinerja yakni, perencanaan, aksi dan evaluasi. Pada sektor perencanaan Madrasah Aliyah Al Ayyubi memiliki program kerja yang telah diselaraskan dengan sasaran dan tujuan madrasah, khususnya dalam upaya memperbaiki kinerja guru dan program kerja tersebut telah disosialisasikan kepada seluruh anggota madrasah.

Pada aksinya, terdapat dua model pembinaan atau pelatihan yang dilakukan oleh pihak madrasah antara lain pelatihan bulanan yang berupa kursus komputer, pelatihan studi kasus. Akan tetapi, para guru kurang antusias dalam mengikuti pelatihan tersebut, terlebih lagi bagi guru-guru senior yang notabene berada di usia tidak muda lagi, mereka menyebutkan kesulitan dalam mengoperasikan komputer sehingga mereka enggan untuk hadir di pelatihan tersebut. Berbeda dengan guru-guru junior yang menyambut baik upaya madrasah tersebut, bahkan mereka ungkapkan upaya ini sangat membantu mereka dalam proses belajar mengajar dengan siswa ataupun untuk menambah pengetahuan dan meningkatkan kemampuan guru secara pribadi.
Proses evaluasi yang ada di Madrasah Aliyah Al Ayyubi ini masih bersifat semiformal, karena metode yang digunakan hanya melalui pengamatan oleh tim evaluator yang dibentuk tanpa ada penentuan skala indikator yang tetap dan evaluasi akhir tahunnya hanya melalui diskusi antara kepala madrasah dan guru yang bersangkutan.

\section{SIMPULAN}

Dari hasil penelitian yang peneliti lakukan di Madrasah Aliyah Al Ayyubi sesuai dengan hasil wawancara dan observasi serta dokumentasi sebagai data pendukung menyebutkan bahwa kinerja guru di Madrasah Aliyah Al Ayyubi ini masih belum memenuhi kualifikasi standar kompetensi kinerja guru yang telah ditetapkan dan disepakati bersama oleh seluruh anggota, mengacu pada Peraturan Menteri Pendidikan Nasional Republik Indonesia Nomor 16 Tahun 2007 tentang Standar Kualifikasi Akademik dan Kompetensi Guru, yakni kompetensi pedagogik, kompetensi kepribadian, kompetensi sosial, dan kompetensi professional. Terutama pada kompetensi pedagogik yang meliputi perancangan dan pelaksanaan pembelajaran, di mana seharusnya guru harus memiliki rencana pembelajaran berupa silabus serta mampu mengelola kelas, memanfaatkan komputer dan LCD sebagai media proses pembelajaran dan membangun keaktifan siswa dalam diskusi interaktif antara guru dan sesama siswa. Guru Madrasah Aliyah Al Ayyubi sebagian besar tidak melakukan hal tersebut, khususnya guru-guru senior dengan keterbatasan kemampuan ketika mengoperasikan komputer dan LCD.

Selain itu, dalam kompetensi kepribadian, di mana seorang guru harusnya mampu menjadi teladan yang digugu lan ditiru atau yang selalu benar dan patut di contoh justru menampakkan 
sikap yang kurang baik. Mengingat bahwa Madrasah Aliyah Al Ayyubi ini merupakan lembaga pendidikan yang juga bernapaskan agama Islam, maka lembaga ini sangat memperhatikan segala tindak laku agar selalu sinkron dengan nilainilai ajaran agama Islam.

Poin plusnya justru terdapat pada kompetensi sosial, sedangkan untuk kompetensi profesional yang dimiliki oleh guru-guru Madrasah Aliyah Al Ayyubi ini sekalipun belum optimal, akan tetapi sudah mempunyai akar fondasi yang bagus.

Sistem manajemen kinerja yang ada di Madrasah Aliyah Al Ayyubi ini dikatakan berjalan hampir 60\%, pada fase perencanaan Madrasah Aliyah Al Ayyubi memiliki program kerja yang telah diselaraskan sesuai kebutuhan dengan visi, misi, sasaran dan strategi madrasah. Akan tetapi pada implementasinya, dari dua model pelatihan yang telah ditetapkan pada program kerja, pelatihan bulanan yang meliputi kursus komputer dan studi kasus, banyak para guru senior yang kurang berpartisipasi, berbeda dengan guru junior yang menyambut baik upaya tersebut.

Kekurangan lain dari sistem manajemen kinerja di Madrasah Aliyah Al Ayyubi ini terletak pada evaluasi kinerja, belum ada format penilaian yang ditetapkan secara resmi dan formal oleh Madrasah Aliyah Al Ayyubi Syadzili dan masih menggunakan metode diskusi dan dengar pendapat secara personal, sekalipun sebelumnya diadakan pengamatan harian, mingguan dan bulanan mengenai kinerja guru dalam hal kedisiplinan dan kompetensi guru.

\section{IMPLIKASI DAN KETERBATASAN}

Dalam melakukan penelitian ini, terdapat beberapa kendala yang terjadi selama proses pengumpulan data yang membatasi hasil penelitian ini. Lebih lanjut akan dibahas mengenai berbagai kendala yang terjadi selama proses penelitian ini berlangsung, dengan penjabaran dan penjelasan berikut ini diharapkan membuka peluang bagi penelitian berikutnya yang relevan dengan penelitian ini. Berikut ini adalah kendalakendala utama yang dihadapi selama penelitian ini berlangsung.

1. Ketidakhadiran informan untuk wawancara Kendala yang dihadapi adalah adanya beberapa informan yang kurang nyaman dengan metode wawancara, sehingga mereka kurang dapat menjelaskan informasi yang dibutuhkan oleh peneliti. Selain itu, sistem monarki yang masih kental di lembaga ini menjadikan beberapa informan ragu-ragu dan merasa takut untuk berbicara terbuka.

2. Penggunaan single case study

Kendala lain yang dihadapi oleh peneliti selama penelitian ini berlangsung adalah penggunaan single case study.

Penggunaan single case study ini menyebabkan hasil penelitian hanya dapat digeneralisasikan terhadap proposisinya dan tidak dapat digeneralisasikan pada lingkup yang lebih luas.

\section{DAFTAR RUJUKAN}

Abidin, N. 2011. A Theory and Practice at AlIzzah Islamic Boarding School. Performance Management Journal. No. 1. Halaman 1-2.

Afifuddin, M.M. 2012. Dasar-Dasar Manajemen. Bandung: ALFABETA.

Aguinis, H. 2009. Performance Management 2nd Edition. New Jersey: Pearson Education.

Admodiwirio, S. 2000. Manajemen Pendidikan Indonesia, Jakarta: PT Ardadizya Jaya.

Aurel, N.B. 2010. Rediscovering Performance Management: System, Learning and Integration. Measuring Business Excellence. Vol. 14, No.1, pp. 109-123. 
Arikunto, S. 2006. Prosedur Penelitian Suatu Pendekatan Praktik. Jakarta: Rineka Cipta. Arifin, M. 2003. Ilmu Perbandingan Pendidikan, Jakarta: Golden Terayon Press.

Bacal, R. 2001. Performance Management. Terjemahan Surya Darma dan Yanuar Irawan. Jakarta: PT. Gramedia Pustaka Utama.

Barney, JB. 2002. Gaining and Sustaining Competitive Advantage 2nd edition. New Jersey: Pearson Education.

Bernardin \& Russel. 2006. Pinter Manajer, Aneka Pandangan Kontemporer. Alih Bahasa Agus Maulana. Jakarta: Penerbit Binarupa Aksara.

Boyd, R.T.C. 1989. Practical Assessment, Research \& Evaluation. Improving Teacher Evaluations. ERIC Digest.

Collis, D.J., \& Montgomery, C.A. 2005. Corporate Strategy: A Resource-Based Approach 2nd Edition. New York: McGraw-Hill/ Irwin.

Conny RS. 1991. Mencari Strategi Pengembangan Pendidikan Nasional Menjelang Abad 21. Jakarta: PT Gramedia.

Daryanto. 2001. Evaluasi Pendidikan. Jakarta: PT Rineka Cipta.

Davis, R.C. 2002. Fundamental of Top Management, Tokyo, Penerbit: Kogakusha Company Limited.

Dessler, Gary. 2003. Manajemen Sumber Daya Edisi Kesepuluh jilid I. Terjemahan Paramita Rahayu. Klaten: Intan Sejati.

Fauzuddin, Y. 2011. Studi Mengenai Organizational Change Berkaitan dengan Implementasi Manajemen Berbasis Sekolah di SMA Negeri 18 Surabaya. Tesis. Surabaya: Magister Manajemen Universitas Airlangga.

Fuad, N. dkk. 2006. Manajemen Madrasah Aliyah Swasta di Indonesia. Pusat Penelitian dan Pengembangan Pendidikan Agama dan Keagamaan.
Guritno, B dan Waridin. 2005. Pengaruh Persepsi Karyawan Mengenai Perilaku Kepemimpinan, Kepuasan Kerja dan Motivasi Terhadap Kinerja. Jurnal Riset Bisnis Indonesia Vol.1 No.1, p. 63-74.

Gibson et al. 1996. edisi ketiga, jilid 1. Jakarta: Erlangga.

Hasibuan, M. 2001. Manajemen Sumber Daya Manusia. Jakarta: Bumi Aksara.

Hamalik, O. 1995. Pendidikan Guru, Konsep dan Strategis. Bandung: Mandar Maju.

Irawan, P. 2006. Penelitian Kualitatif \& Kuantitatif untuk Ilmu-Ilmu Sosial. Departemen Ilmu Administrasi FISIP UI.

Karel A.S. 1986. Pesantren, Madrasah dan Sekolah; Pendidikan Islam dalam Kurun Modern. Terjemahan, hlm. 44. Jakarta: LP3ES.

Kornkasem, J., M. Johdi Salleh, and B. Mohamad. 2010. System of Islamic School Bangkok. Journal Management (1) 1-40.

Mangkunegara, AP. 2004. Manajemen Sumber Daya Manusia cetakan pertama. Bandung: PT Remaja Rosdakarya. 2006. Evaluasi Kinerja SDM. Bandung: Refika Aditama.

Mahmudi. 2007. Manajemen Kinerja Sektor Publik. Yogyakarta: UPP STIM YKPN.

Michel J.L. 1995. Performance measurement and performance management. International Journal of Production Economics. Volume 41, Issues 1-3, France. October 1995, Pages 23-35.

Moeheriono. 2009. Pengukuran Kinerja Berbasis Kompetensi. Bogor: Ghalia Indonesia.

Moleong, L.J. 2007. Metode Penelitian Kualitatif. Bandung: PT Remaja Rosdakarya.

Mujiono. 2011. Pengaruh Kepemimpinan Kepala Sekolah, Iklim Kerja Sekolah Terhadap Kinerja Guru Sekolah Dasar Negeri di Kecamatan Seputih Agung Lampung Te- 
ngah. Jurnal Penelitian Manajemen Pendidikan.

Nakosteen, Mehdi. 1996. Kontribusi Islam Atas Dunia Intelektual Barat; Deskripsi Analisis Abad Keemasan Islam, hal. 66. Surabaya: Risalah Gusti.

Nazir, Moch. 2003. Metode Penelitian, Jakarta: Salemba Empat.

Nasution. 2006. Metode Research (Penelitian Ilmiah). Jakarta: Bumi Aksara, hlm. 29 dan hlm. 72.

Pidarta, M. 1999. Pemikiran tentang Supervisi Pendidikan. Jakarta: Bumi Aksara.

Prahalad, C.K., and G. Hamel. 1990. The Core Competence of the Corporation. Harvard Business Review: May-June 1990 page 79-91.

Pujianto, E. 2013. Manajemen Peningkatan Mutu berbasis sekolah. 12. www.pakguruonline. pendidikan.net diakses tanggal 21 Oktober 2013.

Rachmawati, Eka. 2011. Rancangan Indikator Kinerja Individu untuk Bagian Service dan Bagian Project di PT BIA. Tesis. Surabaya: Magister Manajemen Universitas Airlangga.

Republik Indonesia. 2003. Undang-undang Republik Indonesia No. 20 Tahun 2003 tentang Sisdiknas pasal 39 ayat (2).

Republik Indonesia. 2005. Undang-Undang Republik Indonesia Nomor 14 Tahun 2005 Pasal 20 (a) Tentang Guru dan Dosen.

Republik Indonesia. 2007. Peraturan Menteri Pendidikan Nasional Republik Indonesia No. 16 Tahun 2007 tentang Standar Kualifikasi Akademik dan Kompetensi Guru.

Ruky, A.S. 2001. Sistem Manajemen Kinerja. Jakarta: PT Gramedia Pustaka Utama.

Rusyan, T. 1990. Profesionalisme Tenaga Kependidikan. Bandung: Yayasan Karya Sarjana Mandiri.
Samsudin, S. 2005. Manajemen Sumber Daya Manusia, Bandung: Pustaka Setia.

Sardiman, A.M, 1987. Ilmu Pendidikan, Bandung: Remaja Karya.

Satori, Djam'an dan Aan Komariah. 2009. Metode Penelitian kualitatif. Bandung: Alfabeta.

Seeker, Karen R and JB. Wilson. 2000. Planning Successful Employee Performance. Terjemahan Ramelan. Jakarta: PPM.

Sudrajat, Akhmad. 2008. Manajemen Kinerja Guru. Jurnal Manajemen.

Suharsaputra, U. 2010. Administrasi Pendidikan. Bandung: Refika Aditama.

Sugiyono. 2012. Memahami Penelitian Kualitatif. Bandung: Penerbit Alfabeta.

Sunhaji. 2006. Manajemen Madrasah. Yogyakarta: Grafindo Litera Media.

Terry, R.G. 1962. Office Management and Control, Fourth Edition. Homewood, Illinois: Richard D. Irwin Inc.

Tead, O. 2008. Human Nature and Management. Kessinger Publishing, LLC.

Volansky, A and Isaac A. Friedman. 2003. SchoolBased Management an International Perspective. A journal research.

Veithzal, R. 2005. Performance Appraisal. Jakarta: PT Raja Grafindo.

Wirawan. 2009. Evaluasi Kinerja Sumber Daya Manusia: Teori Aplikasi dan Penelitian. Jakarta: Salemba Empat.

Whindam D.M. 1988. Indicators of Educational Effectiveness and Efficiency. Improving the Efficiency of Educational System. Florida: IEES.

Yuwono, S., dkk. 2002. Petunjuk Praktis Penyusunan Balanced Scorecard: Menuju Organisasi yang Berfokus pada Strategi. Jakarta: PT Gramedia Pustaka Utama.

Zikmund, W.G., Babin, B.J., Carr, J.C., and Griffin, M. 2010. Business Research Methods. South Western: Cencage Learning. 